\title{
Teoria dos princípios e função jurisdicional
}

\section{The theory of principles and the jurisdictional function}

\author{
RICARDO MARCONDES MARTINS \\ Pontifícia Universidade Católica de São Paulo (Brasil) \\ ricmarconde@uol.com.br \\ Recebido/Received: 04.11.2017 / November $4^{\text {th }}, 2017$ \\ Aprovado/Approved: 23.04.2018 / April 23 $3^{\text {rd }}, 2018$
}

\section{Resumo}

Este estudo tem por objeto a teoria dos princípios jurídicos voltada ao exercício da função jurisdicional. Após diferenciar a discricionariedade da interpretação, defende a incompatibilidade entre a primeira e a jurisdição. Princípios jurídicos, hoje, possuem dois significados principais: são elementos estruturantes do sistema normativo e valores positivados. Os dois significados foram propostos como resposta à teoria da discricionariedade jurisdicional. Ambos os significados de princípios podem ser utilizados como instrumento para violação do direito positivo e para fuga do dever de motivar. $\mathrm{O}$ antídoto é o ônus argumentativo imposto ao magistrado quando da invocação de um princípio.

Palavras-chave: princípios jurídicos; discricionariedade; função jurisdicional; valores; norma jurídica.

\section{Abstract}

The subject of this paper is the theory of legal principles as it applies to the exercise of the jurisdictional function. After differentiating discretion from interpretation, this study defends the incompatibility between discretion and jurisdiction. Today, legal principles have two main meanings: they are elements that make up the structure of the normative system and they also constitute asserted values [under positivism]. Both meanings have been proposed as an answer to the theory of jurisdictional discretion. Both meanings of principles can be used as an instrument to violate positive law and to depart from the duty to recite the grounds. The antidote lies in the argumentative burden imposed on the magistrate when invoking a principle.

Keywords: legal principles; discretion; jurisdictional function; values; legal norm.

Como citar esse artigo/How to cite this article: MARTINS, Ricardo Marcondes. Teoria dos princípios e função jurisdicional. Revista de Investigações Constitucionais, Curitiba, vol. 5, n. 2. p. 135-164, mai./ago. 2018. DOI: 10.5380/rinc.v5i2.56183.

* Professor de Direito Administrativo da Graduação, do Mestrado e do Doutorado da Pontifícia Universidade Católica de São Paulo (São Paulo-SP, Brasil). Doutor e Mestre em Direito Administrativo pela Pontifícia Universidade Católica de São Paulo (São Paulo-SP, Brasil).E-mail: ricmarconde@uol.com.br. 


\section{SUMÁRIO}

1. Breve introdução; 2. Função jurisdicional e discricionariedade; 3. Teoria dos princípios jurídicos; 4. Princípios e valores; 5. Princípios e normas; 6. Princípios materiais e formais; 7. Fórmula do peso; 8. Deturpações da teoria dos princípios; 9 . Conclusões; 10. Referências.

\section{BREVE INTRODUÇÃO}

Debateu-se, nas últimas duas décadas, à exaustão, o conceito de princípio. A teoria dos princípios jurídicos tornou-se um assunto da moda. Contemporaneamente, afirma-se que a aplicação do direito não se restringe à subsunção, método de aplicação de regras, mas abrange a ponderação, método de aplicação de princípios. Nesse sentido, o $2^{\circ}$ do artigo 489 do novo Código de Processo Civil (Lei Federal 13.105/15) exige que o magistrado explicite a "ponderação efetuada", no caso de "colisão de normas". O tema é tormentoso: muitos afirmam que a ponderação e a teoria dos princípios são, na verdade, uma nova terminologia para a prática do arbítrio. Ao invés do governo das leis, vivencia-se, segundo muitos, o governo dos juízes, no qual o magistrado, por meio da manipulação retórica de princípios, impõe sua vontade com desprezo pelo Direito. Pretendo, neste estudo, apresentar, do modo mais didático e direto possível, uma teoria sobre os princípios jurídicos com atenção especial para esse problema. Examinarei os princípios e a ponderação à luz do exercício da função jurisdicional. Para cumprir esse objetivo, como ponto de partida, faz-se necessária breve análise conceitual da discricionariedade e da função judicante.

\section{FUNÇÃO JURISDICIONAL E DISCRICIONARIEDADE}

O artigo de Ronald Dworkin intitulado The model of rules, publicado originariamente em 1967, e republicado no Capítulo 2 da obra "Levando o direito a sério" ${ }^{1}$, é o principal marco teórico sobre a atual problemática dos princípios jurídicos. Trata-se de uma crítica à obra "O conceito de direito" de Herbert Hart ${ }^{2}$. Dworkin rebate três teses por ele extraídas dessa obra, assim resumidas: 1) o direito é formado por um conjunto de regras identificadas por regras secundárias, identificação chamada por Dworkin de "teste de pedigree"; 2) o Direito se restringe a esse conjunto de regras e supostamente é aplicado apenas por subsunção; 3) muitas vezes, a aplicação do direito depende da discrição do magistrado. Dworkin nega as três teses: 1) o direito seria formado por regras e por princípios, e estes não são identificados pelo "teste de pedigree"; 2) os princípios não seriam aplicáveis por subsunção; 3 ) o magistrado não possuiria discricionariedade

DWORKIN, Ronald. Levando os direitos a sério. Tradução Nelson Boeira. São Paulo: Martins Fontes, 2002. p. 23-72.

2 HART, H. L. A. O conceito de direito. Tradução de A. Ribeiro Mendes. 3. ed. Lisboa: Calouste Gulbenkian, 2001. 
no exercício da função jurisdicional. Das três teses, interessa-me neste estudo a terceira. Na verdade, esta, a meu ver, diz respeito ao problema que levou Dworkin a formular sua teoria dos princípios, sendo as outras apenas desdobramentos da resposta dada por ele a esse problema. Trata-se de uma questão central da Teoria Geral do Direito, qual seja: quando decide uma questão, o magistrado possui discricionariedade? Dworkin esforçou-se à exaustão para justificar a resposta negativa.

O tema exige definir o significado de "discricionariedade". Dworkin diferencia três sentidos para essa palavra: num primeiro sentido, que ele chama de fraco, a palavra é empregada para se referir às decisões em que os padrões não podem ser aplicados mecanicamente, mas exigem o uso da capacidade de julgar; num segundo, também chamado, por ele, de fraco, a palavra é empregada para se referir aos casos em que um agente é habilitado a dar a última decisão, sem possibilidade de revisão; num terceiro sentido, que ele chama de forte, a palavra é empregada para se referir aos casos em que o agente não é limitado por qualquer padrão jurídico ${ }^{3}$. A discriminação revela a complexidade do problema.

Os dois primeiros sentidos nada têm a ver com o sentido técnico de discricionariedade. Toda decisão jurídica envolve "sensibilidade para as questões humanas" e, por isso, é incompatível com uma operação mecânica. Como bem observa Carlos Ayres Brito, parafraseando Tobias Barreto, a decisão jurídica pressupõe um ato de pensar e um ato de sentir ${ }^{4}$. Logo, mesmo a decisão proferida no exercício de competência vinculada é incompatível com uma operação mecânica. Por outro lado, as decisões do Supremo Tribunal Federal seriam, no segundo sentido, discricionárias. Conforme aqui será defendido, regra geral, não o são. O fato de não caber revisão da decisão em nada interfere em seu caráter vinculado. O terceiro sentido, chamado de forte, aproxima-se mais do sentido técnico, mas só pode ser adotado com severas ressalvas.

Valho-me de uma figura de linguagem para explicar a discricionariedade: a personificação ou prosopopeia, consistente em atribuir qualidades humanas a seres inanimados ${ }^{5}$. Supondo-se que o ordenamento jurídico brasileiro possua uma vontade, quando essa vontade admite apenas uma única decisão (por exemplo: " $x$ "), configura-se a competência vinculada, quando admite duas ou mais decisões (por exemplo, " $x$ " ou " $y$ "), configura-se a competência discricionária. E por que o ordenamento admite duas ou mais decisões? Por força do pluralismo político. Explico: em certas hipóteses, mesmo levando em consideração as pressuposições impostas ao intérprete ${ }^{6}$, bem

\footnotetext{
DWORKIN, Ronald. Levando os direitos a sério... Op. Cit. p. 51-52.

4 BRITTO, Carlos Ayres. O humanismo como categoria constitucional. Belo Horizonte: Fórum, 2007. p. 75.

5 GUIMARÃES, Hélio de Seixas; LESSA, Ana Cecília. Figuras de linguagem: teoria e prática. 14. ed. São Paulo: Atual, 2003. p. 54.

$6 \quad$ Adoto duas teorias sobre a interpretação jurídica. A teoria do legislador racional, formulada por Carlos Santiago Nino, segundo a qual o intérprete deve pressupor que o agente normativo seja único, imperecível,
} 
como o peso das competências estabelecidas no sistema normativo ${ }^{7}$, não é possível dizer que, objetivamente, uma decisão é melhor do que outra. Há, nesses casos, uma impossibilidade de valoração objetiva: a escolha entre uma alternativa e outra é ditada pela opinião de cada um $^{8}$, a valoração é subjetiva e não objetiva. O que faz o Direito nesses casos? Imputa a escolha ao agente competente, constituindo uma competência discricionária.

Há, porém, uma diferença conceitual relevante entre a escolha realizada no âmbito da liberdade e a escolha realizada no âmbito da discricionariedade. No primeiro caso, ao contrário do que ocorre no segundo, ela pode basear-se apenas no livre-arbítrio. Na discricionariedade o agente público deve escolher a alternativa que, segundo suas convicções, melhor realiza o interesse público. Perceba-se: mesmo na competência discricionária, o Direito impõe uma série de condicionamentos à escolha do agente competente; a escolha dá-se em decorrência da convicção subjetiva de que, dentre as alternativas admitidas, a eleita é a melhor para a realização do interesse público; não se fundamenta numa escolha livre, arbitrária, baseada, enfim, no livre-arbítrio. Justamente, por isso, com pena de ouro, observou Caio Tácito que a competência discricionária não é um cheque em branco ${ }^{9}$. Em resumo: sempre que, no exercício da função pública, o Direito aceita como válidas duas ou mais alternativas, imputa a escolha ao agente competente, que deve escolher a partir de sua convicção subjetiva sobre a melhor forma de realizar o interesse público.

Com absoluto acerto, Afonso Rodrigues Queiró observa que a discricionariedade só ocorre após cessada a interpretação ${ }^{10}$. De fato, só após a constatação de qual o sentido e o alcance das normas incidentes, e a "descoberta" de que o direito aceita duas

consciente, onisciente, operante, justo, coerente, onicompreensivo e preciso (SANTIAGO NINO, Carlos. Introdução à análise do direito. Tradução de Elza Maria Gasparotto. São Paulo: WMF Martins Fontes, 2015. p. 386387); e a teoria da interpretação criativa, formulada por Ronald Dworkin, segundo a qual o intérprete deve pressupor dois princípios de integridade política, um imposto ao editor normativo e outro ao aplicador normativo, segundo os quais o Direito deve ser tomado como um todo moralmente coerente (DWORKIN, Ronald. 0 império do direito. Tradução de Jefferson Luiz Camargo. 1. ed. 2. tir. São Paulo: Martins Fontes, 2003. p. 213).

7 O respeito às competências estabelecidas é ditado pelos chamados princípios formais, retomados adiante. Sobre eles vide: MARTINS, Ricardo Marcondes. Teoria dos princípios formais. In: FERNANDES, Felipe Gonçalves (org.). Temas atuais de direito administrativo neoconstitucional. São Paulo: Intelecto, 2016. p. 01-37.

8 Foi o que reconheceu com absoluta precisão Edmund Bernatzik, nos termos expostos por Afonso Rodrigues Queiró: "na aplicação do direito, como também em qualquer outra esfera de actividade lógica do espírito, há um limite além do qual terceiras pessoas deixam de poder avaliar da justeza da conclusão obtida. Por conseguinte, essas terceiras pessoas podem ser de outra opinião, mas não podem legitimamente pretender que só elas tenham uma opinião justa e que a das outras pessoas seja falsa: se o pretendessem, não teriam a generalidade a dar-lhes razão". (BERNATZIK, Edmund. Rechtsprechung und materielle Rechtskraft, 1886. p. 1-46 apud QUEIRÓ, Afonso Rodrigues. 0 poder discricionário da administração. 2. ed. Coimbra: Coimbra, 1948. p. 121).

9 TÁCITO, Caio. O abuso de poder administrativo no Brasil. In: TÁCITO, Caio. Temas de direito público: estudos e pareceres - v. 1. Rio de Janeiro: Renovar, 1997. p. 52.

10 QUEIRÓ, Afonso Rodrigues. A teoria do "desvio de poder" em direito administrativo. Revista de Direito Administrativo, Rio de Janeiro, v. 6. p. 41-78, 1946. p. 67. 
ou mais alternativas como válidas, é que surge a competência para "escolher" entre uma alternativa e outra. Insisto: a discricionariedade só ocorre após a interpretação.

Apresentado o conceito de discricionariedade, passo a examiná-la em relação a cada uma das funções estatais. Ela está presente no exercício da função legislativa e no exercício da função administrativa: o sistema normativo imputa, em diversas hipóteses, tanto ao Legislador como ao Administrador Público a prerrogativa de escolher entre duas ou mais alternativas. Há, porém, três diferenças entre a discricionariedade legislativa e a discricionariedade administrativa, uma quantitativa e duas qualitativas. A quantitativa é de fácil visualização: o Legislador tem seu âmbito decisório restringido pelas normas constitucionais, o Administrador Público tem seu âmbito decisório restringido pelas normas constitucionais e legais. Se uma lei posterior é incompatível com uma lei anterior, há a revogação da lei anterior (Decreto-lei 4.657/42, art. 2º, §2); se um ato administrativo posterior é incompatível com a lei anterior, o ato é, regra geral, inválido ${ }^{11}$. Em termos técnicos: o exercício da discricionariedade é garantido no sistema normativo por um princípio formal, pelo princípio formal que dá primazia às ponderações do Legislador ("Pfl") e pelo princípio formal que dá primazia às ponderações do Administrador ("Pfa"). O "Pfl" restringe o "Pfa", mas a recíproca não é verdadeira; noutras palavras: as decisões legislativas restringem a discricionariedade administrativa, mas nem as decisões legislativas nem as administrativas, regra geral, restringem a discricionariedade legislativa. Logo, o âmbito discricionário do Legislador é bem mais alargado do que o âmbito discricionário do Administrador — diferença quantitativa.

Quando o sistema normativo imputa ao Administrador Público a escolha de um meio de concretização de um valor (de um princípio, conforme adiante explicado), o Administrador deve escolher a melhor medida de concretização, é o que impõe o chamado princípio da boa administração. Esse dever, de escolher a melhor medida, restringe sensivelmente o âmbito da discricionariedade administrativa. Ao revés, o sistema normativo não impõe ao Legislador a escolha da melhor medida: a medida legislativa é válida desde que seja proporcional, ainda que exista outra, no plano abstrato ou no plano concreto, melhor. Trata-se de uma diferença qualitativa entre a competência legislativa e a administrativa, decorrente da incidência, apenas sobre a última, do princípio da boa administração ${ }^{12}$.

Finalmente, na discricionariedade administrativa, vícios de vontade do agente competente interferem na validado do ato. No caso de dolo - de escolha baseada em móvel espúrio - , há presunção absoluta de vício de finalidade ou de contentorização; no caso de erro - de escolha baseada em móvel não espúrio - , há presunção relativa

11 Ressalva-se o afastamento da lei pela ponderação de princípios. Cf.: MARTINS, Ricardo Marcondes. Efeitos dos vícios do ato administrativo. São Paulo: Malheiros, 2008. p. 202 et seq.

12 Sobre o tema vide: MARTINS, Ricardo Marcondes. Proporcionalidade e boa administração. Revista Internacional de Direito Público (RIDP), Belo Horizonte, ano 2, n. 2. p. 09-33, jan./jun. 2017. 
de vício de finalidade ou de contentorização ${ }^{13}$. No primeiro caso, configura-se o desvio de poder. No exercício da função legislativa, o sistema normativo despreza os vícios de vontade do agente competente, o dolo e o erro são, mesmo no exercício de competência discricionária, irrelevantes para a validade do ato ${ }^{14}$. Trata-se, também, de uma diferença qualitativa entre o exercício da discricionariedade legislativa e da administrativa: na primeira, ao contrário do que ocorre na segunda, os vícios de vontade do agente normativo não interferem na validade da norma editada.

Fixadas essas diferenças, passo, finalmente, a examinar a relação entre a função jurisdicional e a discricionariedade. Como regra geral, há incompatibilidade conceitual entre ambas. Oswaldo Aranha Bandeira de Mello qualificou o Judiciário como "oráculo da Constituição"15. Celso Antônio Bandeira de Mello realizou uma extensão muito apropriada: o Judiciário é o "oráculo do Direito"16. É o órgão habilitado a dar a última palavra, para o caso concreto, sobre a interpretação jurídica. Coerentemente, só a norma jurisdicional é dotada do atributo da coisa julgada. A função típica do Poder Judiciário é exercer a jurisdição no sentido etimológico da palavra, ou seja, "dizer o Direito", estabelecer, de modo definitivo, para o caso concreto a interpretação jurídica correta. Não cabe ao Poder Judiciário realizar escolhas entre indiferentes jurídicos, entre alternativas que, num primeiro momento, sejam igualmente válidas.

Darei um exemplo para aclarar o tema. Suponha-se um pedido de antecipação de tutela. Haveria discricionariedade se, para o Direito, fosse, num primeiro momento, válido tanto deferir a antecipação (" $x$ ") como indeferi-la (" $y$ "); admitidas as duas alternativas como juridicamente válidas, caberia ao agente competente, a partir de sua vontade (ato volitivo), simplesmente escolher entre uma alternativa e outra. O juiz, nesse caso, estaria habilitado a escolher a partir de seu íntimo, vale dizer, de suas convicções sobre a melhor forma de realizar o Direito. Conceitualmente, porém, essa não é a explicação correta do fenômeno jurídico. Não cabe ao magistrado escolher, mas interpretar. Ele deve procurar descobrir qual a "vontade" do Direito: o sistema normativo vigente exige que seja deferida a liminar ou que seja indeferida. Trata-se de apurar qual é a correta interpretação - ato cognitivo e não volitivo - , competência vinculada e não discricionária.

\footnotetext{
13 Sobre o tema vide: MARTINS, Ricardo Marcondes. Efeitos dos vícios do ato administrativo... Op. Cit. p. 198 et seq.

14 A inconstitucionalidade da lei não pode fundamentar-se no desvio de poder subjetivo, apenas no objetivo. Por todos: SERRANO, Pedro Estevam Alves Pinto. 0 desvio de poder na função legislativa. São Paulo: FTD, 1997. p. 97-98.

15 BANDEIRA DE MELLO, Oswaldo Aranha Bandeira de Mello. A teoria das constituições rígidas. 2. ed. São Paulo: José Bushatsky, 1980. p. 89-93.

16 BANDEIRA DE MELLO, Celso Antônio. Juízo liminar: poder-dever de exercício do poder cautelar nessa matéria. Revista trimestral de direito público, São Paulo, n. 3. p. 106-116, 1993. p. 114; BANDEIRA DE MELLO, Celso Antônio. Mandado de segurança contra denegação ou concessão de liminar. Revista de direito público, São Paulo, ano 22, n. 92. p. 55-61, out./dez. 1989. p. 58.
} 
Só há uma exceção de exercício de discricionariedade na função jurisdicional. $O$ inciso LXXI do art. 5. da CF/88 assegura a concessão de mandado de injunção para viabilizar o exercício de um direito constitucional sempre que a falta de norma regulamentadora torne inviável o seu exercício. Nesse caso, por expressa disposição constitucional, compete ao Poder Judiciário regulamentar o direito para o caso concreto. Muitas vezes, o sistema normativo aceitará duas ou mais possibilidades de regulamentação, abrindo-se a possibilidade de decisão discricionária no exercício da jurisdição.

\section{TEORIA DOS PRINCÍPIOS JURÍDICOS}

Em sentido diametralmente contrário ao aqui sustentado, no Capítulo VIII da Teoria Pura do Direito, Hans Kelsen defendeu a existência de uma ampla discricionariedade jurisdicional ${ }^{17}$. A norma jurídica seria sempre uma moldura abarcante de várias interpretações, sendo a escolha de uma delas uma decisão política do agente competente. Consequentemente, toda decisão judicial, segundo Kelsen, seria fruto do exercício de uma competência discricionária. Hart foi menos radical, distinguindo os casos paradigmáticos, simples ou claros dos casos difíceis: nos primeiros, há uma resposta certa, inexistindo discricionariedade quando da decisão judicial; nos últimos, em decorrência da textura aberta da linguagem, não haveria como afirmar qual é a resposta correta, configurando-se um autêntico poder discricionário ${ }^{18}$. Como já antecipado, Dworkin tomou como base para sua teoria o texto de Hart.

Antes de examinar a teoria dos princípios de Dworkin, é mister perceber que a expressão "princípio jurídico" é ambígua na Ciência do Direito. Genaro R. Carrió discriminou, em trabalho originalmente publicado em 1970, onze empregos diferentes ${ }^{19}$. No artigo 4. da Lei de Introdução ao Direito Brasileiro (Decreto-lei 4.657/42), a expressão "princípios gerais do direito" é utilizada para se referir a uma técnica de integração: quando os textos legais forem omissos, o juiz está autorizado a resolver o problema jurídico valendo-se da "analogia, dos costumes e dos princípios gerais do direito". O dispositivo faz supor que os princípios jurídicos só têm serventia diante de lacunas, entendidas como inexistência de uma resposta expressa na literalidade dos textos normativos. Nada mais equivocado. De todos os significados atribuídos, no Direito, à palavra princípio, destaco três. Como se apresentaram numa sucessão cronológica, qualifico-os como "fases" do conceito.

\footnotetext{
17 KELSEN, Hans. Teoria pura do Direito. Tradução de João Baptista Machado. 6. ed. Coimbra: Arménio Amado, 1984. p. 469-471.

18 HART, H. L. A. O conceito de direito... Op. Cit. p. 137-168.

19 CARRIÓ, Genaro R. Notas sobre derecho y lenguaje. 4. ed. 2. reimpr. Buenos Aires: Albeledo-Perrot, 1998. p. 209-212.
} 
Na primeira, foi utilizada no Direito tendo em vista o sentido da palavra na linguagem comum ou natural: como princípio significa origem, início, foi utilizada para se referir às questões gerais de uma dada disciplina, aos temas que devem ser apresentados a quem inicia seu estudo. Foi nesse sentido que a palavra foi empregada por Oswaldo Aranha Bandeira de Mello e por Ruy Cirne Lima no título de suas obras mestras. ${ }^{20}$ Essa primeira fase está hoje absolutamente superada: ninguém mais emprega, na Teoria do Direito, a expressão com esse significado.

Na segunda, a palavra foi dissociada do sentido comum ou natural e passou a ser empregada em sentido técnico para identificar apenas as ideias chave, as vigas mestras, os alicerces do sistema normativo. Princípios jurídicos são, nesse sentido, os elementos estruturantes do sistema normativo. Trata-se de um conceito da Teoria Geral dos Sistemas: os sistemas possuem uma parte-dirigente e tendem a centralizar-se ao redor dela. ${ }^{21}$ Na doutrina brasileira, a segunda fase foi difundida por Celso Antônio Bandeira de Mello ${ }^{22}$ e por Geraldo Ataliba. ${ }^{23}$

Se apresentarmos todos os Códigos para um leigo e solicitarmos a ele que leia os textos normativos, não tardará muito para que se perca. Será surpreendente se chegar ao trigésimo artigo. Não é assim que um estudante de Direito lida com os Códigos: mais do que aprender os textos dos milhares de dispositivos, o estudante aprende, no curso de Direito, os elementos aglutinadores das normas, que dão racionalidade, coerência, ao todo. Ele aprende os princípios jurídicos, no significado consagrado pela aqui chamada segunda fase.

Essa fase foi uma importante resposta à tese da discricionariedade judicial. No difundido conceito de Celso Antônio Bandeira de Mello, o princípio é uma "disposição fundamental que se irradia sobre diferentes normas, compondo-lhes o espírito e servindo de critério para exata compreensão e inteligência"24. Logo, não se abre ao magistrado a prerrogativa de "escolher" entre uma ou outra interpretação. Ele deve eleger a mais afinada com os princípios jurídicos, que são "vetores para soluções interpretativas" 25 .

Ronald Dworkin propõe um novo significado para a palavra "princípio", dando início à terceira fase. A expressão "princípio jurídico" passa a ser utilizada para

20 BANDEIRA DE MELLO, Oswaldo Aranha. Princípios gerais de direito administrativo - v. 1. 3. ed. São Paulo: Malheiros, 2007; CIRNE LIMA, Ruy. Princípios de direito administrativo. 7. ed. São Paulo: Malheiros, 2007.

21 Cf. BERTALANFFY, Ludwig von. Teoria geral dos sistemas. Tradução de Francisco M. Guimarães. 3. ed. Petrópolis: Vozes, 2008. p. 103.

22 BANDEIRA DE MELLO, Celso Antônio. Criação de secretarias municipais: inconstitucionalidade do art. 43 da Lei Orgânica dos Municípios do Estado de São Paulo. Revista de Direito Público, São Paulo, ano IV, v. 15. p. 284-288, jan./mar. 1971; BANDEIRA DE MELLO, Celso Antônio. Curso de direito administrativo. 33. ed. São Paulo: Malheiros, 2016. p. 53-54.

23 ATALIBA, Geraldo. Sistema constitucional tributário brasileiro. São Paulo: Revista dos Tribunais, 1968. p. 4-21.

24 BANDEIRA DE MELLO, Celso Antônio. Curso de direito administrativo... Op. Cit. p. 54 e 990-991,

25 CARRAZZA, Roque. Curso de direito constitucional tributário. 18. ed. São Paulo: Malheiros, 2002. p. 35. 
denominar as normas jurídicas que apenas estabelecem uma razão para uma decisão. Diz Dworkin: as regras se submetem à "regra do tudo ou nada", pois, caso inexista outra regra superior que as invalide (critério hierárquico) ou outra regra posterior que as revogue (critério cronológico) ou outra regra que as excepcione (critério da especialidade), elas devem, se ocorrido o fato descrito em sua hipótese (subsunção), ser aplicadas; já os princípios possuem diferentes pesos e, por isso, não se submetem à regra do tudo ou nada, podendo num caso serem aplicados e no outro não, sem perder sua vigência e sua validade ${ }^{26}$.

Robert Alexy, no capítulo terceiro de sua obra Teoria dos direitos fundamentais, a partir da proposta de Dworkin, propõe conceitos mais técnicos: as regras são determinações no âmbito das circunstâncias fáticas e jurídicas, os princípios são mandados de optimização no âmbito das circunstâncias fáticas e jurídicas ${ }^{27}$. Em trabalho específico sobre o tema, Alexy observa que a regra do tudo ou nada não funciona como aparentemente parece funcionar. Uma regra pode não ser aplicada e continuar vigente e válida apesar de inexistir outra regra superior, posterior ou especial. Isso porque por trás de toda regra está um princípio e este pode colidir com princípios opostos levando ao afastamento da regra. Dessarte: a ponderação de princípios pode levar ao estabelecimento de uma exceção implícita à regra; logo, regras não são afastadas apenas por outras regras, mas também pela ponderação de princípios ${ }^{28}$.

Um dos traços fundamentais da distinção entre regras e princípios, proposta na terceira fase, é que os princípios positivam um valor a ser concretizado, sem definir o meio de concretização, enquanto as regras estabelecem o meio de concretização de um valor. Trata-se da famosa distinção de Niklas Luhmann entre programação finalística e programação condicional29. Um exemplo: suponha-se a intenção de que um local seja limpo. Pela programação finalística, própria da normatização por princípios, exige-se a limpeza do local, na maior medida possível, deixando-se em aberto a escolha dos meios para realização da empreitada; pela programação condicional, própria da normatização por regras, fixa-se uma série de procedimentos, que devem necessariamente ser adotados, com a convicção de que, se cumpridos, o local restará limpo.

A terceira fase do conceito de princípio também foi uma importante resposta à teoria da discricionariedade jurisdicional. O Direito deixa de ser compreendido como

\footnotetext{
26 DWORKIN, Ronald. Levando os direitos a sério... Op. Cit. p. 39 et seq.

27 ALEXY, Robert. Teoria dos direitos fundamentais. Tradução de Virgílio Afonso da Silva. São Paulo: Malheiros, 2008. p. 90-91.

28 ALEXY, Robert. Sobre o conceito de princípio jurídico. In: ALEXY, Robert. Teoria discursiva do direito. Organização, tradução e estudo introdutório de Alexandre Travessoni Gomes Trivisonno. Rio de Janeiro: Forense, 2014. p. 163-198.

29 LUHMANN, Nicklas. Sociologia do Direito II. Tradução de Gustavo Bayer. Rio de Janeiro: Tempo Brasileiro, 1985. p. 27-34. Sobre ela vide: FERRAZ JR., Tércio Sampaio. Teoria da norma jurídica. 4. ed. Rio de Janeiro: Forense, 2002. p. 109.
} 
um conjunto de imputações alicerçadas apenas na vontade dos agentes competentes; assume-se que o conjunto de normas pressupõe um conjunto de valores e a missão do Direito é concretizá-los na maior medida possível. Retomo a relação entre os princípios e os valores adiante. O modo como a terceira fase contribui para o afastamento da discricionariedade é visualizado pela forma como os princípios são aplicados, tema também retomado adiante.

São correntes dois equívocos desastrosos em relação ao tema. Primeiro: desprezar a ambiguidade e tratar os conceitos da segunda e da terceira fase como se tivessem a mesma referência. ${ }^{30}$ Enfatiza-se: trata-se de conceitos distintos. Princípios na segunda fase dizem respeito aos elementos estruturantes do sistema (ou subsistema) normativo; na terceira, dizem respeito às normas que exigem a realização máxima de um valor. Certos princípios da segunda fase não são princípios na terceira e vice-versa: o princípio da anterioridade tributária e o princípio da motivação, por exemplo, são dois elementos estruturantes, respectivamente, do regime jurídico tributário e do administrativo, mas não são mandados de otimização e, sim, determinações no âmbito fático e jurídico, autênticas regras jurídicas. Por outro lado, o princípio da proteção à intimidade é um típico mandado de otimização — proteja-se a intimidade na maior medida possível —, mas não é indicado como um elemento estruturante do direito privado.

O segundo equívoco, também bastante comum, é mais grave: desprezar um dos conceitos, como se o outro não tivesse préstimo científico. Quem nega o conceito da segunda fase, nega a existência de uma Ciência do Direito: sem os elementos estruturantes, o conjunto normativo deixa de ser um "ordenamento" e passa a ser um mero amontoado de normas. Sem sistema, não há ciência, é a velha lição de Immanuel Kant. ${ }^{31}$ Por outro lado, a correta aplicação do Direito dá-se pela ponderação e pela subsunção, de modo que, quem nega o conceito da terceira fase, restringe a aplicação à subsunção e, assim, a uma aplicação jurídica equivocada. Por isso, há que se manter a ambiguidade na linguagem jurídica: as duas referências são indispensáveis e, infelizmente, são denominadas pelo mesmo rótulo.

Adotados os dois significados e, portanto, superado o segundo equívoco, impende fazer a seguinte observação: quem se vale da expressão "princípio jurídico" deve, para evitar o primeiro equívoco mencionado, caso o contexto não deixe claro, indicar em que sentido a emprega.

\footnotetext{
30 O equívoco é criticado tanto por Celso Antônio Bandeira de Mello (Curso de direito administrativo... Op. Cit., Cap. I-rodapé 35. p. 54), como por Virgílio Afonso da Silva (A constitucionalização do direito. São Paulo: Malheiros, 2005. p. 36).

31 KANT, Immanuel. Crítica da razão pura. Tradução de Valerio Rohden e Udo Baldur Moosburger. São Paulo: Nova Cultural, 1999. p. 492.
} 


\section{PRINCÍPIOS E VALORES}

O Tribunal Constitucional Alemão, no famoso caso Lüth (BVerfGE 7, 198), afirmou:"a Constituição, que não pretende ser uma ordenação axiologicamente neutra, [...] também estabeleceu, na seção dedicada aos direitos fundamentais, uma ordem objetiva de valores" ${ }^{\prime \prime 2}$. Em assonância com esse entendimento da Corte, Robert Alexy afirma que os princípios só diferem dos valores tendo em vista o plano em que se encontram: valores estão no plano axiológico, referem-se ao que é bom ou ruim; princípios estão no plano deôntico, referem-se ao que é devido ou indevido ${ }^{33}$. No mais, valores e princípios equiparam-se integralmente. Perceba-se: princípios, na terceira fase, são valores positivados no ordenamento jurídico.

A percepção de que princípios (no sentido da terceira fase) e valores se equiparam, ressalvada apenas a diferença de plano, é importante por força do seguinte desdobramento: as características dos valores estendem-se integralmente aos princípios. Destaco seis atributos ${ }^{34}$. 1) Os valores - e, pois, os princípios - são relativos: a importância do valor depende sempre das circunstâncias fáticas e jurídicas do caso concreto ${ }^{35}$. 2) Os valores são históricos: surgem e desaparecem ao longo do tempo, de modo que algo que era valorizado no passado, não é valorizado hoje e vice-versa ${ }^{36}$. Por consequência, novos princípios são descobertos, outros são considerados superados. 3) Os valores são precários: até por decorrência de sua historicidade, desaparecem com o tempo. 4) Os valores são indeterminados: são insuscetíveis de uma discriminação exaustiva. Em relação aos princípios, a indeterminação é reforçada pela assunção na ordem constitucional do pluralismo político como fundamento do Estado brasileiro. O pluralismo consiste na pressuposição de que as pessoas têm diferentes visões de mundo, todas igualmente respeitáveis. A Constituição exige, por isso, que o catálogo de valores constitucionais esteja sempre em aberto, pois, do contrário, estar-se-ia consagrando a visão de mundo de quem estabeleceu a discriminação. Por conseguinte, sempre há a possibilidade de, pela argumentação jurídica, alguém demonstrar a existência de um princípio constitucional implícito, ainda não antevisto pela comunidade jurídica. 5) Os valores são imbricativos: implicam-se reciprocamente, no sentido de que nenhum deles se realiza sem influir na realização dos demais ${ }^{37}$. Por isso, os princípios estão sempre em

\footnotetext{
32 ALEXY, Robert. Teoria dos direitos fundamentais... Op. Cit. p. 154. Sobre o caso Lüth vide: SCHWABE, Jürgen. Cinquenta anos de jurisprudência do tribunal constitucional federal alemão. Tradução Beatriz Hennig et al. Montevideo: Konrad-Adenauer-Stiftung, 2005. p. 381-394; MARTINS, Ricardo Marcondes. Abuso de direito e a constitucionalização do direito privado. São Paulo: Malheiros, 2010. p. 75 et seq.

33 ALEXY, Robert. Teoria dos direitos fundamentais... Op. Cit. p. 153.

34 Cf. MARTINS, Ricardo Marcondes. Efeitos dos vícios do ato administrativo... Op. Cit. p. 298-306; Abuso de direito e constitucionalização do direito privado... Op. Cit. p. 35-38.

35 Sobre a relatividade dos valores vide, por todos: REALE, Miguel. Filosofia do direito. 19. ed. 3. tir. São Paulo: Saraiva, 2002. p. 189.

36 Idem. p. 208.

37 Idem. p. 189.
} 
conflito. É fácil perceber o caráter conflitivo nos casos paradigmáticos como o direito à informação e a proteção da privacidade, mas toda decisão jurídica pressupõe a escolha de um valor em detrimento de outro. 6) Os valores são insuscetíveis de uma ordenação hierárquica fixa, mas admitem uma ordenação hierárquica branda ${ }^{38}$. Se fosse possível uma ordenação rígida e, pois, a afirmação de que um princípio sempre prevalece sobre outro, configurar-se-ia uma tirania dos valores e, pois, a visão de mundo de quem estabeleceu a ordenação. Isso não significa que seja impossível estabelecer, no plano abstrato, uma ordenação branda. Deveras, a ordem constitucional não estabelece o mesmo peso para todos os princípios. Basta um exemplo: a dignidade da pessoa humana não possui, no plano abstrato, o mesmo peso da economicidade. Daí a existência de uma ordenação branda dos princípios, "branda" porque a superioridade de peso no plano abstrato deve ser confirmada no caso concreto, pois é perfeitamente possível que, nas circunstâncias do caso, a ordem se inverta.

Ainda sobre os valores jurídicos e os princípios faço duas observações. Primeira: há quem defenda que a dignidade da pessoa humana seria um princípio absoluto. Em 2008 dei um exemplo para demonstrar o desacerto dessa tese: afirmei que o sistema prisional brasileiro violava a dignidade da pessoa humana ${ }^{39}$. Muitos anos depois, no julgamento da Medida Cautelar da ADPF 347, o STF me deu razão: o sistema carcerário brasileiro ofende a dignidade e configura um "estado de coisas inconstitucional" ${ }^{\prime \prime 0}$. Ora, nenhum jurista considera que, diante da violação da dignidade, deve-se liberar todos os presos, independente da periculosidade. Como a reforma penitenciária, por mais eficiente que seja, leva algum tempo para ser realizada, todos admitem uma provisória violação da dignidade. Logo, não existem princípios absolutos, o peso de cada princípio depende sempre da análise das circunstâncias fáticas e jurídicas do caso concreto.

Segunda observação: a relatividade dos princípios não implica a subjetividade da valoração. Para Kelsen, por exemplo, as valorações seriam sempre subjetivas, inerentes ao pluralismo político e, por conseguinte, a definição do que é certo e do que é errado, do ético ou do não ético, depende sempre da opinião de cada um ${ }^{41}$. Basta um singelo exemplo para demonstrar o desacerto dessa tese: ainda que alguém considere correto aprisionar judeus em campos de concentração, isso é errado. Há valorações objetivas, que independem da opinião de cada um, próprias do exercício de competência

\footnotetext{
38 ALEXY, Robert. Teoria dos direitos fundamentais... Op. Cit. p. 160 et seq.

39 MARTINS, Ricardo Marcondes. Efeitos dos vícios do ato administrativo... Op. Cit. p. 301.

40 STF, ADPF 347 MC/DF, Pleno, Rel. Min. Marco Aurélio, j.09.09.15, DJe-031, divulg. 18.02.16. Constou da ementa: "Cabível é a arguição de descumprimento de preceito fundamental considerada a situação degradante das penitenciárias no Brasil. Presente quadro de violação massiva e persistente de direitos fundamentais, decorrente de falhas estruturais e falência de políticas públicas e cuja modificação depende de medidas abrangentes de natureza normativa, administrativa e orçamentária, deve o sistema penitenciário nacional ser caraterizado como 'estado de coisas inconstitucional'".

41 Cf. KELSEN, Hans. O problema da justiça. Tradução João Baptista Machado. 4. ed. São Paulo: Martins Fontes, 2003. p. 69-71; Teoria pura do direito... Op. Cit. p. 100-101.
} 
vinculada, e valorações subjetivas, que dependem da opinião de cada um, próprias do exercício de competência discricionária.

\section{PRINCÍPIOS E NORMAS}

A pergunta que se faz é: princípios são normas jurídicas? Na segunda fase, princípios não eram considerados normas, mas vetores para interpretação das normas. De fato, tanto Geraldo Ataliba como Celso Antônio diferenciavam os princípios das normas $^{42}$ : o sistema normativo seria um conjunto de normas presidido pelos princípios, cuja missão é fazer com que o conjunto normativo não seja apenas uma soma de normas, mas um ordenamento, um sistema, vale dizer, um todo harmônico e coerente. $\mathrm{Na}$ terceira fase, princípios passam a ser considerados uma espécie de norma jurídica. Contudo, para saber se princípio - na terceira fase - é ou não norma jurídica, deve-se fixar o significado desta. Como todo conceito básico da Teoria Geral do Direito, o conceito de norma jurídica é problemático, há diversas propostas teóricas.

Robert Alexy, por exemplo, adota um conceito semântico de norma: é o significado de um enunciado normativo ${ }^{43}$. Concordo parcialmente. De acordo com uma diferenciação já consagrada, a norma jurídica não se confunde com o texto normativo ${ }^{44}$. Apesar de aceitar essa diferenciação, discordo da Escola Genovesa: a norma não é estabelecida pelo intérprete a partir da leitura do texto normativo, ela é "descoberta" pelo intérprete ${ }^{45}$. Do contrário, o editor normativo seria o intérprete e não o agente competente. Quem produz a norma é o editor, quando da enunciação do texto. A norma "está" no texto e precisa ser "descoberta" pelo intérprete.

Norma, para mim, é uma padronização, por meio da abstração, da ocorrência de determinado fenômeno. Ela sempre obedece a um esquema lógico, em que o consequente é condicionado a um antecedente: se a hipótese, deve ser a consequência ( $H$ $\rightarrow C)^{46}$. Nas normas naturais a consequência é associada a hipótese por um vínculo de

\footnotetext{
42 Nas palavras de Celso Antônio Bandeira de Mello: "violar um princípio é muito mais grave que transgredir uma norma". BANDEIRA DE MELLO, Celso Antônio. Criação de secretarias municipais... Op. Cit. p. 285. Nas palavras de Geraldo Ataliba: "sistema normativo é o conjunto unitário e ordenado de normas, em função de uns tantos princípios fundamentais, reciprocamente harmônicos, coordenados em torno de um fundamento comum". (Sistema constitucional tributário brasileiro... Op. Cit. p. 19).

43 ALEXY, Robert. Teoria dos direitos fundamentais... Op. Cit. p. 54.

44 Por todos: GUASTINI, Riccardo. Das fontes às normas. Tradução Edson Bini. São Paulo: Quartier Latin, 2005. p. 34-36; GRAU, Eros Roberto. Por que tenho medo dos juízes. 7. ed. São Paulo: Malheiros, 2016. p. 39-41.

45 Sobre a posição da Escola Genovesa, por todos: GUASTINI, Riccardo. Das fontes às normas... Op. Cit. p. 136138; GRAU, Eros Roberto. Por que tenho medo dos juízes... Op. Cit. p. 41; CARVALHO, Paulo de Barros. Direito tributário, linguagem e método. São Paulo: Noeses, 2008. p. 129-131.

46 Sobre o conectivo lógico "condicional" vide, por todos: ECHAVE, Delia Teresa; URQUIJO, María Eugenia; GUIBOURG, Ricardo A. Lógica, proposición y norma. 6. reimpr. Buenos Aires: Astrea, 2002. p. 56-62. Sobre a estrutura lógica da norma jurídica vide, por todos: VILANOVA, Lourival. As estruturas lógicas e o sistema do direito positivo. São Paulo: Max Limonad, 1997. p. 95 et seq.
} 
causalidade, em decorrência de uma imposição da Natureza; trata-se de um vínculo ôntico, próprio do ser (se a hipótese, é a consequência). Nas de comportamento a consequência é associada à hipótese por um vínculo de imputação, em decorrência da atuação humana; trata-se de um vínculo deôntico, próprio do dever-ser (se a hipótese, deve ser a consequência) ${ }^{47}$. As normas morais, religiosas, jurídicas são normas de comportamento. O que distingue as jurídicas das demais? Acolho a proposta de Goffredo Telles Junior: normas jurídicas são imperativos autorizantes ${ }^{48}$, pois, ao contrário das demais normas de comportamento, que também são imperativas, elas autorizam alguém a obter de um órgão estatal o cumprimento forçado ${ }^{49}$. Na feliz expressão de Paulo de Barros Carvalho, a norma jurídica é a "expressão irredutível de manifestação do deôntico" 50 .

Fixado o conceito de norma, retomo o problema: princípios, na terceira fase, são normas, mas para entender essa assertiva deve-se atentar para duas classificações das normas jurídicas, didaticamente apresentadas por Norberto Bobbio. Observa o aclamado jusfilósofo que a restrição das normas às gerais e abstratas baseia-se num preconceito ideológico: como a abstração garante a segurança e a generalidade garante a igualdade, difundiu-se a restrição $0^{51}$. Contudo, as normas podem ter: destinatário universal (gerais); destinatário singular (individuais); prescrição com ação universal (abstratas); prescrição com ação singular (concretas) ${ }^{52}$. Leis, sentenças, atos administrativos,

47 Sobre a diferença entre o princípio da causalidade e o princípio da imputação vide, por todos: KELSEN, Hans. Causalidade e imputação. In: KELSEN, Hans. O que é a Justiça? Tradução Luís Carlos Borges. 3. ed. São Paulo: Martins Fontes, 2001. p. 323-348.

48 TELLES JUNIOR, Goffredo. O direito quântico. 6. ed. São Paulo: Max Limonad, 1985. p. 347.

49 A estrutura lógica da norma jurídica desdobra-se em duas partes: a norma primária, em que no antecedente está previsto um fato ou um conjunto de fatos e no consequente está prevista, configurada no mundo fenomênico a hipótese, a instituição de duas situações jurídicas (efeito unilateral da norma) e de uma relação entre elas (efeito bilateral da norma); e a norma secundária, em que no antecedente prevê-se a violação da norma primária e no consequente a relação processual em que se pleiteia ao órgão estatal a coação necessária para que a norma seja cumprida. Sobre o conceito de situação jurídica vide, por todos: PERLINGIERI, Pietro. Perfis do direito civil: introdução ao direito civil constitucional. Tradução Maria Cristina De Cicco. 2. ed. Rio de Janeiro: Renovar, 2002. p. 105 et seq. A relação jurídica não consiste apenas na ligação entre um direito subjetivo e um dever ou obrigação, ao contrário do que se pensava no passado. Segundo bem ensina Perlingieri, "a relação sob o perfil estrutural é uma relação entre situações complexas". (Idem. p. 116).

50 CARVALHO, Paulo de Barros. Direito Tributário: fundamentos jurídicos da incidência. 2. ed. São Paulo: Saraiva, 1999. p. 17. Para o autor as duas normas que compõem a norma completa estão vinculadas pelo conectivo lógico includente. Nas palavras dele: "As duas entidades que, juntas, formam a norma completa, expressam a mensagem deôntica-jurídica na sua integralidade constitutiva, significando a orientação da conduta, juntamente com a providência coercitiva que o ordenamento prevê para o seu descumprimento. Em representação formal: $D\{(p \rightarrow q) \vee[(p \rightarrow-q) \rightarrow S]\}$. Ambas são válidas no sistema, ainda que somente uma venha a ser aplicada ao caso concreto. Por isso mesmo, empregamos o disjuntor includente (" $v$ ") que suscita o trilema: uma ou outra ou ambas. A utilização desse disjuntor tem a propriedade de mostrar que as duas regras são simultaneamente válidas, mas que a aplicação de uma exclui a da outra". (Direito tributário: linguagem e método... Op. Cit. p. 139).

51 BOBBIO, Norberto. Teoria da norma jurídica. Tradução Fernando Pavan Baptista e Ariani Bueno Sudatti. Bauru: Edipro, 2001. p. 182. A restrição é, de fato, bastante difundida. Apenas a título de exemplo, Riccardo Guastini impõe às normas a generalidade e a abstração. GUASTINI, Riccardo. Las fuentes del derecho: fundamentos teóricos. Traducción César E. Moreno More e Luis Cárdenas Rodríguez. Lima: Raguel, 2016. p. 52-53.

52 Idem. p. 179. 
contratos privados são veículos introdutores de normas gerais e abstratas, gerais e concretas, individuais e abstratas, individuais e concretas ${ }^{53}$. Ademais, Bobbio classifica as normas jurídicas em dois grupos: as normas de comportamento e as normas de estrutura (também chamadas de normas de competência ou normas secundárias): as primeiras disciplinam a conduta, as últimas disciplinam a produção das normas ${ }^{54}$. Como bem observa Paulo de Barros Carvalho, em rigor ambas são normas de comportamento, pois as de estrutura disciplinam a conduta dos agentes normativos ${ }^{55}$.

Expostas resumidamente as duas classificações, antes de explicar a estrutura normativa dos princípios, faz-se, ainda, necessário observar o seguinte: os princípios, na terceira fase, são valores positivados; logo, toda regra concretiza um ou mais valores, vale dizer, um ou mais princípios. Em síntese: por trás de toda regra ("R") existe um princípio ("P"). Trata-se da aplicação da teoria do círculo hermenêutico à compreensão do fenômeno normativo ${ }^{56}$. Mais precisamente, trata-se da chamada teoria da concretização constitucional, segundo a qual todo o fenômeno jurídico dá-se em prol da concretização dos princípios constitucionais, de modo que as normas estão dispostas numa ordem hierárquica tendo em vista, segundo José Joaquim Gomes Canotilho, sua abertura semântica: princípios constitucionais estruturantes $\leftrightarrow \leftrightarrow$ princípios constitucionais gerais $\leftrightarrow \leftrightarrow$ princípios constitucionais especiais $\leftrightarrow \leftrightarrow$ regras constitucionais $\leftrightarrow \leftrightarrow$ regras legislativas $\leftrightarrow \leftrightarrow$ regras administrativas e jurisdicionais ${ }^{57}$. Uso o bicondicional para indicar que as normas estão num "processo biunívoco de esclarecimento recíproco" 58 , vale dizer, as normas mais abertas são concretizadas pelas mais fechadas e compreendidas à luz delas e as normas mais fechadas concretizam as mais abertas e são compreendidas à luz delas.

Com essa explicação, é possível apresentar a estrutura normativa dos princípios. Eles, de fato, na terceira fase, são normas jurídicas e, portanto, apresentam a estrutura

53 Sobre a teoria dos veículos introdutores vide: MOUSSALLEM, Tárek Moysés. Fontes do direito tributário. São Paulo: Max Limonad, 2011. p. 133 et seq.; MARTINS, Ricardo Marcondes. Efeitos dos vícios do ato administrativo... Op. Cit. p. 105 et seq.

54 BOBBIO, Norberto. Teoria do ordenamento jurídico. 10. ed. Brasília: Universidade de Brasília 1999. p. 45.

55 CARVALHO, Paulo de Barros. Direito tributário: fundamentos jurídicos da incidência... Op. Cit. p. 35.

56 A teoria do círculo hermenêutico foi inicialmente elaborada por SCHLEIERMACHER, Friedrich D. E. Hermenêutica: arte e técnica da interpretação. Tradução de Celso Reni Braida. 4. ed. Bragança Paulista: Editora Universitária São Francisco, 2003. p. 47. Foi aprofundada por: GADAMER, Hans-Georg. Verdade e método II. Tradução de Ênio Paulo Giachini. Petrópolis: Vozes, 2002. p. 72 et seq. E estendida ao direito por LARENZ, Karl. Metodologia da ciência do direito. Tradução de José Lamego. 3. ed. Lisboa: Fundação Calouste Gulbenkian, 1997. p. 285-293, 452 e 621.

57 CANOTILHO, José Joaquim Gomes. Direito constitucional e teoria da Constituição. 4. ed. Coimbra: Almedina, 2000. p.1139. A teoria da concretização constitucional foi pioneiramente desenvolvida por: HESSE, Konrad. Temas fundamentais do direito constitucional. Textos selecionados e traduzidos por Carlos dos Santos Almeida et al. São Paulo: Saraiva, 2009. p. 108-109.

58 CANOTILHO, José Joaquim Gomes. Direito constitucional e teoria da Constituição... Op. Cit. p. 1139. 
"H $\rightarrow \mathrm{C}^{\text {"59 }}$. Há, contudo, que distinguir: no Direito Público, os princípios são normas de estrutura de dupla estrutura; no Direito Privado, os princípios também possuem dupla estrutura, mas são normas de estrutura e normas de conduta.

No Estado de Direito, nenhuma atuação estatal é válida se não consistir na consequência de uma norma jurídica, seja uma norma abstrata, seja uma norma concreta. $\mathrm{O}$ Estado não possui liberdade; consequentemente, os agentes públicos não podem atuar com fundamento no livre-arbítrio ${ }^{60}$. A atuação de quem exerce uma função estatal seja a função legislativa, seja a administrativa, seja a jurisdicional — deve dar-se sempre em cumprimento de uma norma jurídica. Por isso, afirmo: os princípios são, no Direito Público, quer dizer, no âmbito da atuação estatal, sempre normas de estrutura, eles disciplinam a edição de regras. São normas de estrutura de dupla estrutura ${ }^{61}$.

Primeira estrutura da norma princípio no Direito público: a hipótese é a edição de uma regra - seja ela qual for — e a consequência é uma relação jurídica entre o editor da regra e os destinatários, sendo que a norma princípio impõe ao editor o dever de levar em consideração o peso do respectivo princípio concretizado pela regra, realizar uma ponderação entre ele e os princípios colidentes e levar em consideração o resultado dessa ponderação no conteúdo da regra editada. Perceba-se: sempre que o Legislador for editar uma norma legislativa - introduzida, regra geral, pelo veículo introdutor da lei - deve realizar uma prévia ponderação; sempre que o Administrador Público editar uma norma administrativa — introduzida, regra geral, pelo veículo introdutor do ato administrativo - , deve realizar uma prévia ponderação; e sempre que o magistrado editar uma norma jurisdicional - introduzida, regra geral, pelo veículo introdutor da sentença - , deve realizar uma prévia ponderação. O exercício das funções estatais dá-se pela edição de normas e estas pressupõem a realização da ponderação em decorrência da imposição da norma do respectivo princípio. Ao contrário do que supunha Kelsen, a edição de uma regra não pode alicerçar-se apenas na opinião do agente competente, ela deve fundamentar-se, sempre, na ponderação dos princípios constitucionais.

Segunda estrutura da norma princípio no Direito público: a hipótese refere-se a certas circunstâncias que atribuem ao princípio um peso tal que leve à incidência da norma princípio; a consequência é uma relação jurídica entre o agente público e o destinatário em que o agente tem o dever de editar uma regra que concretize o respectivo princípio e o destinatário o direito de exigir a edição dessa regra. A hipótese na primeira estrutura é relativamente fechada: o fato da edição de uma regra jurídica.

59 Marcelo Neves também atribui aos princípios a estrutura ou "caráter proposicional": NEVES, Marcelo. Entre Hidra e Hércules: princípios e regras constitucionais. São Paulo: Martins Fontes, 2013. p. 122-124.

60 Cf. MARTINS, Ricardo Marcondes. Teoria jurídica da liberdade. São Paulo: Contracorrente, 2015. p. 106 et seq.

61 Cf. MARTINS, Ricardo Marcondes. Efeitos dos vícios do ato administrativo... Op. Cit. p. 30-33. 
Ao revés, a hipótese na segunda estrutura é aberta: são circunstâncias fáticas que façam com que o princípio tenha um peso tal que leve à sua incidência, impondo ao agente competente o dever de editar uma regra que concretize o princípio. Dou o seguinte exemplo: imagine-se o fato de uma pessoa estar jogada ao relento, num logradouro público, e que inexista uma regra abstrata que exija da Administração Pública o asseguramento a essa pessoa de um teto, um albergue; o fato de ela não ter, por sua conta, condições de arrumar um teto dá ao princípio constitucional do direito à habitação um peso tal que impõe ao Administrador Público a edição de uma regra, no caso, um ato administrativo, que concretize esse princípio, assegurando ao administrado o direito ao teto ${ }^{62}$.

Os particulares, ao contrário dos agentes públicos, possuem liberdade: uma esfera de condutas facultadas, em que é permitido fazer e é permitido não fazer, deixando-se a escolha ao livre-arbítrio. Nesse âmbito, a conduta do particular não decorre do cumprimento de uma norma jurídica, a norma nem lhe obriga, nem lhe proíbe a conduta $^{63}$. Ademais, o direito permite que os particulares editem normas jurídicas privadas, introduzidas, em geral, pelos contratos; porém, como os particulares não estão, entre si, numa relação de supremacia, mas, sim, numa relação horizontal, a validade das normas privadas exige a aquiescência ou concordância dos destinatários ${ }^{64}$. Tendo em vista essas particularidades do espaço privado, os princípios, no Direito Privado, são normas de estrutura, quando disciplinam a edição de normas privadas, e são normas de conduta, quando disciplinam a realização da conduta privada (diversa da edição de normas). São, portanto, também normas de dupla estrutura ${ }^{65}$.

Primeira estrutura da norma princípio no Direito privado: de modo equivalente à primeira estrutura da norma princípio no Direito público, a hipótese refere-se à edição de uma regra jurídica pelos particulares - e, por isso, trata-se de norma de estrutura —; a consequência é a relação jurídica entre o particular que edita a regra e os demais, em que o editor tem o dever de levar em consideração o peso do respectivo princípio concretizado pela regra, realizar uma ponderação entre ele e os princípios colidentes e levar em consideração o resultado dessa ponderação no conteúdo da regra editada. Há uma aplicabilidade imediata dos direitos fundamentais às relações privadas e, por força dela, o dever imposto aos particulares de realizar uma ponderação sempre que

\footnotetext{
62 A Constituição exige do Estado brasileiro a proteção do mínimo vital, independentemente da vontade dos agentes competentes. Trata-se, pois, de competência vinculada e não de discricionária. Cf. MARTINS, Ricardo Marcondes. Teoria jurídica da liberdade... Op. Cit. p. 152-154.

63 Sobre o espaço privado vide: MARTINS, Ricardo Marcondes. Teoria jurídica da liberdade... Op. Cit. p. 37 et seq.

64 Idem. p. 48 et seq.

65 Cf. MARTINS, Ricardo Marcondes. Abuso de direito e constitucionalização do direito privado... Op. Cit. p. 94-99.
} 
celebrem um contrato ${ }^{66}$. A ponderação indicará se subsiste a liberdade ou se os princípios opostos afastam-na, impondo um dever de não fazer ou, excepcionalmente, um dever de suportar. A ponderação de princípios, por si, sem prévia ponderação legislativa, não pode resultar na imposição de uma obrigação de fazer ${ }^{67}$.

Segunda estrutura da norma princípio no Direito privado: a hipótese é a realização de uma conduta (diversa da edição de uma norma privada), a consequência é o dever imposto ao agente de realizar uma ponderação entre o princípio restringido pela conduta e o princípio material da liberdade, e levar em consideração o resultado dessa ponderação. Esta indicará se subsiste ou não o âmbito da atuação facultada ou se os princípios colidentes impõem uma obrigação de não fazer ou, excepcionalmente, uma obrigação de suportar.

\section{PRINCÍPIOS MATERIAIS E FORMAIS}

Robert Alexy divide os princípios — no sentido, por evidente, da terceira fase em dois grupos: materiais e formais ${ }^{68}$. Os materiais dividem-se em princípios relativos a direitos subjetivos e princípios relativos a bens coletivos ${ }^{69}$, ambos se referem a um valor específico positivado no sistema. Exemplo de princípio relativo a direito subjetivo é a intimidade e exemplo de princípio relativo a bem coletivo é o meio ambiente; exigem que se proteja na maior medida possível, respectivamente, a intimidade e o meio ambiente. Os princípios formais não se referem a um valor específico, mas a uma decisão: exigem que seja respeitada, na maior medida possível, a decisão adotada, seja ela qual for.

A teoria dos princípios formais é envolta em controvérsias ${ }^{70}$. Extravasa os limites deste estudo examiná-las. Restringir-me-ei aqui a associá-la ao exercício da função jurisdicional. Certos princípios formais - que chamo de fundamentais ${ }^{71}$ — têm a importante missão de assegurar o respeito ao exercício da competência discricionária dos agentes públicos e da liberdade dos particulares. Assim, por exemplo, quando

66 Sobre o tema vide: MARTINS, Ricardo Marcondes. Abuso de direito e constitucionalização do direito privado... Op. Cit. p. 74 et seq.; MARTINS, Ricardo Marcondes. Teoria jurídica da liberdade... Op. Cit. p. 81-98.

67 Cf. MARTINS, Ricardo Marcondes. Abuso de direito e constitucionalização do direito privado... Op. Cit. p. 109-115; MARTINS, Ricardo Marcondes. Estudos de direito administrativo neoconstitucional. São Paulo: Malheiros, 2015. p. 480 et seq.

68 ALEXY, Robert. Princípios formais. In: TRIVISONNO, Alexandre Travessoni Gomes et al. (Org.). Princípios formais e outros aspectos da teoria discursiva do direito. Rio de Janeiro: Forense Universitária, 2014. p. 3-36.

69 ALEXY, Robert. El concepto y la validez del derecho. Traducción Jorge M. Seña. 2. ed. Barcelona: Gedisa, 2004. p. 179 et seq.; Direitos individuais e bens coletivos. In: ALEXY, Robert. Direito, razão, discurso: estudos para a filosofia do direito. Tradução Luís Afonso Heck. Porto Alegre: Livraria do Advogado, 2010. p. 176-198.

70 Sobre o tema vide: MARTINS, Ricardo Marcondes. Teoria dos princípios formais... Op. Cit.

71 MARTINS, Ricardo Marcondes. Abuso de direito e a constitucionalização do direito privado... Op. Cit. p. 40 et seq. 
o Legislador adota uma decisão, o princípio material concretizado por sua decisão é acrescido de um peso, decorrente do princípio formal que dá primazia às ponderações do Legislador ("P1 + Pfl”). Do mesmo modo, quando o Administrador Público adota uma decisão, o princípio material concretizado por sua decisão é acrescido de um peso adicional, decorrente do princípio formal que dá primazia às ponderações do Administrador ("P1 + Pfa"). Como o Poder Judiciário, no exercício da função jurisdicional, não exerce competência discricionária, não há que se falar em princípio formal que dá primazia às ponderações do Poder Judiciário. Há, porém, um princípio formal - que chamo de especial ${ }^{72}$ - que acresce um peso ao princípio material concretizado pela decisão judicial: trata-se do princípio do respeito ao precedente.

Um exemplo facilitará a compreensão do tema. Compete ao Legislador realizar o programa constitucional e, para tanto, ele deve verificar quais princípios (valores positivados) estão expressa ou implicitamente previstos na Constituição, escolher um deles para realizá-lo por meio do estabelecimento, no plano abstrato, de um meio de concretização. Suponhamos que o Legislador resolva concretizar o princípio de proteção ao meio ambiente ("P1"). Para tanto, edita uma lei determinado aos proprietários de veículos automotores que instalem um filtro em seu veículo, sob pena de apreensão pela Administração Pública. Para editar essa lei, o Legislador teve que realizar uma ponderação, no plano abstrato, entre o princípio da proteção ao meio ambiente ("P1") e os princípios colidentes, como a proteção da propriedade privada, da liberdade, do direito de ir e vir (identificados aqui como "P2"). No caso concreto, deve a Administração verificar se apreende ou não o veículo. Ao se deparar com um veículo sem filtro, ela deve fazer uma nova ponderação, mas não entre "P1"e "P2", mas entre "P1 + Pfl" e "P2". Regra geral, cumprirá a lei, tendo em vista o peso de "Pfl". Suponha-se, porém, que o veículo sem filtro seja uma ambulância, que esteja levando alguém ao hospital. Nesse caso, o veículo não deverá ser apreendido, pois o princípio da proteção à vida é mais pesado, no caso concreto, que o princípio da proteção ao meio ambiente, mesmo considerando o peso adicional dado pelo princípio formal que dá primazia às ponderações do Legislador ("P2 > P1 + Pfl").

Mesmo quando inexiste lei, incide o princípio formal que dá primazia às ponderações do legislador, pois há uma decisão deste em prol do princípio material da liberdade. Noutras palavras: na falta da lei, o princípio material da liberdade ("P1"), concretizado pela inação estatal, é acrescido do peso adicional do princípio formal que dá primazia às ponderações do Legislador ("Pfl"). Por isso, na falta de lei, regra geral, a Administração está proibida de atuar. Excepcionalmente, porém, um princípio oposto pode afastar o peso de "P1 + Pfl", justificando a edição de um ato administrativo; nesse

72 MARTINS' Ricardo Marcondes. Abuso de direito e a constitucionalização do direito privado... Op. Cit. p. 52 et seq. 
caso a atuação administrativa fundamentar-se-á não na lei, mas no princípio mais pesado ("P2").

Perceba-se: a ponderação legislativa não é restringida pelo peso do princípio formal que dá primazia às ponderações do Legislador, mas tanto a ponderação administrativa como a jurisdicional são restringidas por ele. Ademais, a ponderação administrativa não é restringida pelo peso do princípio formal que dá primazia às ponderações do Administrador, mas a ponderação jurisdicional é restringida por ele. Quer dizer: o magistrado não pode realizar a ponderação de princípios com desprezo às competências constitucionais. Deve, pois, levar em consideração o peso dos respectivos princípios formais.

Como antecipado, para função jurisdicional, não há um princípio formal fundamental, próprio da competência discricionária e da liberdade, mas há um especial. Se o magistrado decidir num caso de uma maneira, não pode, logo em seguida, decidir caso similar de outra. Haveria evidente violação da igualdade. Mesmo não havendo vinculação formal do precedente - que exige, na Civil Law, expressa previsão nos textos normativos, como ocorre, por exemplo, com as súmulas vinculantes do STF -, há vinculação material: para afastar um precedente, impõe-se ao magistrado um ônus argumentativo, deve demonstrar, na motivação, ou que as circunstâncias do caso são diferentes, ou que houve erro in judicando quando da prolação da decisão anterior. Esse ônus é imposto pelo princípio formal que exige o respeito, na maior medida possível, à decisão jurisdicional anterior ${ }^{73}$.

\section{FÓRMULA DO PESO}

A teoria da ponderação vem sendo acusada, por muitos, de ser irracional ${ }^{4}$. Seria uma forma de legitimar decisões arbitrárias do Poder Judiciário, adotadas com desprezo ao direito positivo. Tratar-se-ia da consagração do "governo dos juízes" ou, mais apropriadamente, da "tirania do judiciário". Os textos normativos passariam a ter préstimo algum, pois, a partir de sua íntima convicção sobre a ponderação de valores, o juiz decidiria o conflito a ele submetido com total desprezo às ponderações do Constituinte, do Legislador e do Administrador público.

Como resposta a essas críticas, no intuito de atribuir o máximo possível de racionalidade à ponderação, tornando-a passível de pleno controle, Robert Alexy propôs a fórmula do peso ${ }^{75}$. Peso em alemão é Gewicht, sendo útil, em português, utilizar a letra

73 Cf. MARTINS, Ricardo Marcondes. Teoria dos princípios formais... Op. Cit. p. 30-33.

74 Sobre o tema vide: ALEXY, Robert. Direitos fundamentais, ponderação e racionalidade. In: ALEXY, Robert. Constitucionalismo discursivo. Tradução de Luís Afonso Heck. Porto Alegre: Livraria do Advogado, 2007. p. 105-116.

75 Sobre o tema vide: ALEXY, Robert. A fórmula do peso. In: ALEXY, Robert. Constitucionalismo discursivo. Tradução de Luís Afonso Heck. Porto Alegre: Livraria do Advogado, 2007. p. 131-153; Teoria dos direitos fundamentais... Op. Cit., Posfácio. p. 393 et seq. 
"G", e não "P", para que não haja confusão com "princípio". Alexy se refere à "Gi,j", para indicar o peso concreto do Princípio "i" (que prefiro chamar de "P1") tendo em vista o princípio "j" (que prefiro chamar de "P2"). A fórmula evidencia que o peso concreto de um princípio nunca é apurado de modo isolado, sempre tem em vista o princípio colidente. A fórmula é uma formalização da chamada, por ele, lei da ponderação: "quanto maior for o grau de não satisfação ou de afetação do princípio, tanto maior terá que ser a importância da satisfação do outro"76.

Alexy explica que a reação entre "P1" e"P2" não é compatível com a "fórmula da diferença" (P1 - P2) e sim com a "fórmula do cociente" (P1/P2) ${ }^{77}$. Ele propõe uma escala triádica: leve, médio e grave. Assim, a realização do princípio "P1" pode ser leve, média e intensa e, da mesma forma, a afetação do princípio oposto, "P2", pode ser leve, média e grave. É intuitivo, observa Alexy, que os intervalos entre os graus devem ser maiores. Por isso, propõe os valores: $2^{0} 2^{0}(=1) ; 2^{1} 2^{1}(=2)$ e $2^{2} 2^{2}(=4)$ para simbolizar "I", "m" e " $\mathrm{g}^{\prime 78}$. Logo, a fórmula do peso, por força dessa progressão geométrica, exige a fórmula do cociente, e não a fórmula da diferença, que seria compatível com a progressão aritmética.

Alexy observa que os princípios possuem diferentes pesos no plano abstrato e essa diferença deve ser levada em consideração no plano concreto. Como já afirmado aqui, a dignidade da pessoa humana não tem o mesmo peso, na Constituição, que a economicidade. Os pesos abstratos são simbolizados por "G1" e "G2". Assim, não há que se confundir: o peso concreto de $\mathrm{P} 1$ tendo em vista $P 2\left(\mathrm{G}_{\mathrm{p} 1_{1}, \mathrm{p}_{2}} \mathrm{G}_{\mathrm{p}_{1}, \mathrm{P} 2}\right)$ com o peso abstrato de $P 1\left(G_{p_{1}} G_{p_{1}}\right)$. Se os pesos abstratos de ambos os princípios forem iguais, eles se anulam na fórmula ${ }^{79}$.

O aclamado jurista também concluiu que o Direito não admite o exercício da competência discricionária apenas quando há certeza das circunstâncias fáticas e jurídicas. O Direito admite que decisões sejam tomadas mesmo na falta de certeza, daí a segunda lei da ponderação: "quanto mais intensa for a intervenção em um direito fundamental, tanto maior terá que ser a certeza das premissas nas quais essa intervenção se baseia" ${ }^{80}$. Basta um exemplo para evidenciar o acerto dessa lei doutrinária: suponha-se que um edifício ameace ruir; na vida real, os engenheiros não dizem à Administração que às tantas horas do dia tal o edifício ruirá; dizem que há grande probabilidade de o edifício ruir. Em tutela da segurança pública e privada, deverá a Administração interditar o edifício e, dependo do caso, até mesmo demoli-lo. Perceba-se: quanto maior a probabilidade, mais legitimada será a interdição, quanto menor a probabilidade, me-

76 ALEXY, Robert. Teoria dos direitos fundamentais... Op. Cit. p. 167 e 604.

77 ALEXY, Robert. A fórmula do peso... Op. Cit. p. 145-146.

78 Idem. Ibidem.

79 Idem. p. 148-149.

80 ALEXY, Robert. Teoria dos direitos fundamentais... Op. Cit. p. 618. 
nos legitimada será a interdição. A incerteza pode dizer respeito às premissas fáticas ou empíricas e às premissas jurídicas ou normativas. Alexy utiliza a letra "S" da palavra "segurança" em alemão (Sicherheit) para simbolizar o grau de certeza na fórmula do peso. Enuncia, então, a equação da certeza para se referir a ambas: grau de certeza empírica do princípio "P1" multiplicado por grau de certeza normativa do princípio "P1"81.

A fórmula do peso completa indica os três fatores referidos: 1) o grau de intervenção da medida concreta em P1 e P2; 2) o peso abstrato de P1 e P2; 3) o grau de certeza das premissas empíricas e normativas de P1 e P2 ${ }^{82}$. Há três possibilidades. 1) $\mathrm{O}$ resultado da fórmula pode ser positivo, ou seja, igual ou superior a 1. Nesse caso, "P1" deve, nas respectivas circunstâncias fáticas do caso, prevalecer sobre "P2": "P1 > P2". 2) $\mathrm{O}$ resultado da fórmula pode ser negativo, ou seja, igual ou inferior a -1 . Nesse caso, "P2' deve, nas respectivas circunstâncias fáticas, prevalecer sobre "P2". 3) O resultado da fórmula pode ser igual a zero, significando que a competência é discricionária, vale dizer, para o Direito, tanto é válida a concretização de "P1" como é válida a concretização de "P2". Nesse caso, o Judiciário deve respeitar a decisão legislativa, administrativa ou privada. Nos dois primeiros casos, há vinculação e, pois, a possibilidade de substituição jurisdicional: no primeiro, se concretizado "P2" pelo Legislador e/ou pelo Administrador, cabe ao Judiciário, quando provocado, invalidar a decisão e determinar a concretização de "P1"; no segundo, se concretizado "P1", cabe ao Judiciário invalidar a decisão e determinar a concretização de "P2". No terceiro caso, a substituição da decisão legislativa e/ou administrativa pelo Judiciário configura violação da separação de poderes, típico ativismo judicial violador da Constituição ${ }^{83}$.

\section{DETURPAÇÕES DA TEORIA DOS PRINCÍPIOS}

Carlos Ari Sundfeld faz uma crítica contundente à teoria dos princípios: eles seriam "armas de espertos e de preguiçosos" 84 , no sentido de que quando o direito positivo contraria os interesses do jurista, os princípios são uma eficaz ferramenta para obter uma decisão contrária ao direito positivo — "arma de espertos" —; ademais, diante da preguiça de buscar argumentos, os princípios são um argumento "fácil", uma forma de contornar o dever de motivar — "arma de preguiçosos". Concordo integralmente com a crítica: por mais que esteja convencido da imprescindibilidade científica da teoria dos

\footnotetext{
81 ALEXY, Robert. Principios formales: algunas respuestas a los críticos. In: PORTOCARRERO QUISPE, Jorge. Ponderación y discrecionalidad. Tradução de Jorge Portocarrero Quispe. Bogotá: Universidad Externado de Colombia, 2016. p. 23-57; Princípios formais... Op. Cit. p. 03-36.

82 ALEXY, Robert. A fórmula do peso... Op. Cit. p. 152-153.

83 Sobre a substituição jurisdicional na competência vinculada e discricionária, vide: MARTINS, Ricardo Marcondes. Efeitos dos vícios do ato administrativo... Op. Cit. p. 586-591.

84 SUNDFELD, Carlos Ari. Princípio é preguiça? In: SUNDFELD, Carlos Ari. Direito administrativo para céticos. 2. ed. São Paulo: Malheiros, 2014, 205-229.
} 
princípios, não tenho como negar que, de fato, na realidade doutrinária e jurisprudencial brasileira, princípios tornaram-se um perigoso expediente de espertos e perigosos. Na minha leitura, o ínclito publicista refere-se ao conceito próprio da segunda-fase princípio como elemento estruturante - , mas sua crítica pode ser perfeitamente estendida ao conceito da terceira fase - princípio como valor positivado.

Carlos Ari, ao menos nesse texto, não volta sua crítica ao instituto dos princípios, mas ao uso que deles se faz. In verbis: "o problema não está neles, mas na comodidade que podem oferecer para os espertos e para os preguiçosos" ${ }^{\prime \prime 5}$. Tanto a teoria dos princípios da segunda fase, como a teoria dos princípios da terceira fase dão ao intérprete um grande poder. Perceba-se: diante da estrutura hierárquica do sistema normativo, considerando que as vigas mestras do sistema - ao menos boa parte delas - e os valores positivados - ao menos boa parte deles —estão expressos ou implícitos na Constituição, tanto os princípios da segunda fase como os princípios da terceira fase são dotados de supremacia em relação às demais normas do sistema. Assim, leis, atos administrativos, contratos e condutas privadas podem ser considerados ilícitos porque violadores dos alicerces do sistema jurídico (princípio na segunda fase) ou da proporcionalidade, e, pois, do peso dos valores positivados (princípio na terceira fase). Daí o risco percebido por Carlos Ari: a possibilidade de os princípios serem incorretamente invocados para afastar decisões válidas. Trata-se do "governo dos Juízes", do "arbítrio jurisdicional", do desprezo, por meio da teoria dos princípios, aos textos normativos vigentes.

O segundo risco é tão grave quanto o primeiro. Direito não costuma ser levado a sério, infelizmente. A teoria dos princípios é valiosa para quem não leva o Direito a sério. Explico: ao invés de buscar os argumentos corretos para uma decisão, invoca-se um princípio - v.g., da dignidade da pessoa humana - como uma "expressão mágica". Não há que examinar os textos normativos, basta invocar a expressão mágica para fundamentar uma sentença. Tanto a utilização "esperta" como a utilização "preguiçosa" dos princípios importam no fim do Estado de Direito.

A solução não está no sepultamento da teoria. O próprio Carlos Ari Sundfeld dá a resposta: tudo se resolve pelo ônus argumentativo ${ }^{86}$. Aliás, é a mesma resposta dada por Robert Alexy: a teoria dos direitos fundamentais pressupõe a teoria da argumentação jurídica. Nas palavras dele: "uma ponderação é racional quando o enunciado de preferência, ao qual ela conduz, pode ser fundamentado de forma racional"87. Quem se vale da teoria dos princípios - seja a teoria da segunda fase, seja a da terceira

85 SUNDFELD, Carlos Ari. Princípio é preguiça? In: SUNDFELD, Carlos Ari. Direito administrativo para céticos. 2. ed. São Paulo: Malheiros, 2014, p. 215.

86 Idem. p. 215.

87 ALEXY, Robert. Teoria dos direitos fundamentais... Op. Cit. p. 165. O tradutor desse texto preferiu a palavra "sopesamento" à "ponderação". Prefere-se, nesse ponto, a tradução de Ernesto Garzón Valdés (Teoría de los derechos fundamentales. 1. ed. 3. reimpr. Madri: Centro de Estudios Políticos y Constitucionales, 2002. p. 159). 
fase - tem um grande ônus argumentativo. Vigora, em relação aos princípios, a regra do $\S 1^{\circ}$, II, do artigo 489 do CPC/2015: não se considera fundamentada a decisão que empregar conceitos jurídicos indeterminados, sem explicar o motivo concreto de sua incidência no caso. Tanto o conceito de princípio da primeira fase como o da segunda são indeterminados para os fins dessa regra. Não basta, pois, invocar um "princípio" para motivar uma decisão.

Em relação ao conceito da segunda fase, deve-se sempre levar em consideração o aqui já referido processo biunívoco de esclarecimento recíproco: não apenas as normas semanticamente fechadas devem ser compreendidas à luz das semanticamente abertas, mas estas devem ser compreendidas à luz daquelas. Assim, a invocação de um princípio estruturante não dispensa o intérprete de examinar, com cuidado, as razões pelas quais normas mais semanticamente fechadas devem, eventualmente, ser afastadas. Insisto: quando uma lei contraria um princípio, não basta a invocação deste para ser adotada decisão contrária ao texto da lei; faz-se necessário explicitar as razões pelas quais a lei não deve ser aplicada.

Em relação ao conceito da terceira fase, impõe-se a explicitação das razões pelas quais um princípio prevalece sobre os outros. Faz-se necessário observar o grau de concretização do princípio, o grau de afetação dos demais, os respectivos pesos abstratos, o grau de certeza das premissas fáticas e jurídicas. E principalmente: o peso dos princípios formais. Não pode o magistrado desprezar a incidência dos princípios formais e desconsiderar as competências estabelecidas no sistema. Justamente por força dessa última assertiva, o texto normativo deve ser levado a sério. $\mathrm{O}$ afastamento de um texto normativo exige cuidado redobrado ${ }^{88}$.

\section{CONCLUSÕES}

1. Discricionariedade é a competência para escolher, a partir de convicções subjetivas sobre a melhor forma de realizar o interesse público, entre duas alternativas igualmente admitidas pelo Direito. É um ato volitivo que pressupõe a interpretação, ato cognitivo. Há uma diferença quantitativa entre a discricionariedade legislativa e a administrativa, pois a segunda, ao contrário da primeira, é restringida pelas decisões legislativas. Há duas diferenças qualitativas: só na administrativa, por força do princípio da boa administração, impõe-se a escolha da melhor medida para o interesse público; só na administrativa os vícios de vontade fazem presumir a invalidade.

2. A discricionariedade é - excetuado o mandado de injunção — incompatível com o exercício da função jurisdicional. O Judiciário é, pois, o oráculo do Direito, o órgão encarregado de dar a última palavra sobre as interpretações jurídicas. Não compete a

88 Para uma teoria hermenêutica respeitante do texto normativo vide: MARTINS, Ricardo Marcondes. Regulação administrativa à luz da Constituição Federal. São Paulo: Malheiros, 2010. Cap. 1. p. 41-71. 
ele realizar escolhas sobre indiferentes jurídicos, mas dizer, quando provocado, qual é a vontade do Direito.

3. A teoria dos princípios jurídicos passou por três fases: na primeira, superada, eram assim chamados todos os assuntos gerais de uma dada disciplina; na segunda, princípios são os elementos estruturantes do sistema normativo; na terceira, são os valores jurídicos positivados. Tanto a segunda como a terceira fase, não superadas, foram importantes reações à tese da discricionariedade jurisdicional. Pelo conceito da segunda fase, ao magistrado não se abre a possibilidade de escolher entre uma ou outra interpretação: deve escolher a interpretação mais coerente com os princípios jurídicos. Pelo conceito da terceira fase, as decisões jurídicas não são fruto do arbítrio, mas resultado da ponderação dos valores constitucionais.

4. Princípios na terceira fase são valores positivados. Logo, as características dos valores - relatividade, historicidade, precariedade, indeterminabilidade, imbricação, não suscetibilidade à ordenação hierárquica rígida - estendem-se aos princípios. A relatividade não implica a subjetividade da valoração. Há valorações objetivas, que independem da opinião da cada um, próprias da competência vinculada; e há valorações subjetivas, dependentes da opinião de cada um, próprias da competência discricionária.

5. Na segunda fase, princípios não eram considerados normas jurídicas, mas vetores de interpretação das normas. Na terceira, são espécies de normas. Estas possuem a estrutura lógica "H $\rightarrow$ C"; princípios, como toda norma, também possuem essa estrutura. No Direito público, são normas de estrutura de dupla estrutura. No direito privado também possuem dupla estrutura, mas são normas de estrutura e de conduta.

6. Na terceira fase os princípios classificam-se em materiais e formais. Os últimos determinam que uma decisão, seja ela qual for, seja respeitada na maior medida possível. O exercício da discricionariedade e da liberdade assenta-se num princípio formal fundamental. Como o Poder Judiciário não exerce discricionariedade, não há um princípio formal fundamental a respaldar suas decisões. Há, contudo, um princípio especial, que impõe o respeito ao precedente.

7. Diante das críticas à teoria dos princípios na terceira fase, propõe-se a fórmula peso como expediente a tornar a ponderação de princípios mais racional e controlável. A fórmula leva em consideração três fatores: a) o grau de intervenção sobre os princípios incidentes; b) o peso abstrato dos princípios incidentes; c) o grau de certeza sobre as premissas fáticas e jurídicas que o envolvem.

8. A teoria dos princípios, tanto na segunda fase como na terceira, pode ser arma de espertos e de preguiçosos. No primeiro caso, é utilizada para violação do direito positivo; no segundo para violação do dever de motivar. A teoria, em ambos os casos, é mortal para o Estado de Direito. 
9. O antídoto está no ônus argumentativo. Sempre que o magistrado invocar um princípio para a prolação de uma decisão judicial, impõe-se uma motivação específica. No conceito da segunda fase, deve explicar a razão pela qual normas semanticamente mais fechadas são afastadas; no conceito da terceira fase, deve explicitar as razões pelas quais atribuiu o respectivo peso ao princípio prevalente e ao colidente, bem como examinar os fatores que interferem na fórmula do peso; em ambos os casos, deve atentar para os princípios formais.

\section{REFERÊNCIAS}

ALEXY, Robert. Teoria dos direitos fundamentais. Tradução de Virgílio Afonso da Silva. São Paulo: Malheiros, 2008.

ALEXY, Robert. Sobre o conceito de princípio jurídico. In: ALEXY, Robert. Teoria discursiva do direito. Organização, tradução e estudo introdutório de Alexandre Travessoni Gomes Trivisonno. Rio de Janeiro: Forense, 2014. p. 163-198.

ALEXY, Robert. Princípios formais. In: TRIVISONNO, Alexandre Travessoni Gomes et al. (Org.). Princípios formais e outros aspectos da teoria discursiva do direito. Rio de Janeiro: Forense Universitária, 2014. p. 3-36.

ALEXY, Robert. El concepto y la validez del derecho. Traducción Jorge M. Seña. 2. ed. Barcelona: Gedisa, 2004.

ALEXY, Robert. Direitos individuais e bens coletivos. In: ALEXY, Robert. Direito, razão, discurso: estudos para a filosofia do direito. Tradução Luís Afonso Heck. Porto Alegre: Livraria do Advogado, 2010. p. 176-198.

ALEXY, Robert. Direitos fundamentais, ponderação e racionalidade. In: ALEXY, Robert. Constitucionalismo discursivo. Tradução de Luís Afonso Heck. Porto Alegre: Livraria do Advogado, 2007. p. 105-116.

ALEXY, Robert. A fórmula do peso. In: ALEXY, Robert. Constitucionalismo discursivo. Tradução de Luís Afonso Heck. Porto Alegre: Livraria do Advogado, 2007. p. 131-153.

ALEXY, Robert. Principios formales: algunas respuestas a los críticos. In: PORTOCARRERO QUISPE, Jorge. Ponderación y discrecionalidad. Tradução de Jorge Portocarrero Quispe. Bogotá: Universidad Externado de Colombia, 2016. p. 23-57.

ALEXY, Robert. Teoría de los derechos fundamentales. 1. ed., 3. reimpr. Madri: Centro de Estudios Políticos y Constitucionales, 2002.

ATALIBA, Geraldo. Sistema constitucional tributário brasileiro. São Paulo: Revista dos Tribunais, 1968. 
BANDEIRA DE MELLO, Celso Antônio. Juízo liminar: poder-dever de exercício do poder cautelar nessa matéria. Revista trimestral de direito público, São Paulo, n. 3. p. 106-116, 1993.

BANDEIRA DE MELLO, Celso Antônio. Mandado de segurança contra denegação ou concessão de liminar. Revista de direito público, São Paulo, ano 22, n. 92. p. 55-61, out./dez. 1989.

BANDEIRA DE MELLO, Celso Antônio. Criação de secretarias municipais: inconstitucionalidade do art. 43 da Lei Orgânica dos Municípios do Estado de São Paulo. Revista de Direito Público, São Paulo, ano IV, v. 15. p. 284-288, jan.-mar. 1971.

BANDEIRA DE MELLO, Celso Antônio. Curso de direito administrativo. 33. ed. São Paulo: Malheiros, 2016.

BANDEIRA DE MELLO, Oswaldo Aranha Bandeira de Mello. A teoria das constituições rígidas. 2. ed. São Paulo: José Bushatsky, 1980.

BANDEIRA DE MELLO, Oswaldo Aranha Bandeira de Mello. Princípios gerais de direito administrativo - v. 1. 3. ed. São Paulo: Malheiros, 2007.

BERTALANFFY, Ludwig von. Teoria geral dos sistemas. Tradução de Francisco M. Guimarães. 3. ed. Petrópolis: Vozes, 2008.

BOBBIO, Norberto. Teoria da norma jurídica. Tradução Fernando Pavan Baptista e Ariani Bueno Sudatti. Bauru: Edipro, 2001.

BOBBIO, Norberto. Teoria do ordenamento jurídico. 10. ed. Brasília: Universidade de Brasília 1999.

BRITTO, Carlos Ayres. O humanismo como categoria constitucional. Belo Horizonte: Fórum, 2007.

CANOTILHO, José Joaquim Gomes. Direito constitucional e teoria da Constituição. 4. ed. Coimbra: Almedina, 2000.

CARRAZZA, Roque. Curso de direito constitucional tributário. 18. ed. São Paulo: Malheiros, 2002.

CARVALHO, Paulo de Barros. Direito tributário, linguagem e método. São Paulo: Noeses, 2008.

CARVALHO, Paulo de Barros. Direito Tributário: fundamentos jurídicos da incidência. 2. ed. São Paulo: Saraiva, 1999.

CARRIÓ, Genaro R. Notas sobre derecho y lenguaje. 4. ed. 2. reimpr. Buenos Aires: Albeledo-Perrot, 1998.

CIRNE LIMA, Ruy. Princípios de direito administrativo. 7. ed. São Paulo: Malheiros, 2007.

DWORKIN, Ronald. Levando os direitos a sério. Tradução Nelson Boeira. São Paulo: Martins Fontes, 2002. 
DWORKIN, Ronald. 0 império do direito. Tradução de Jefferson Luiz Camargo. 1. ed. 2. tir. São Paulo: Martins Fontes, 2003.

ECHAVE, Delia Teresa; URQUIJO, María Eugenia; GUIBOURG, Ricardo A. Lógica, proposición y norma. 6. reimpr. Buenos Aires: Astrea, 2002.

FERRAZ JR., Tércio Sampaio. Teoria da norma jurídica. 4. ed. Rio de Janeiro: Forense, 2002.

GADAMER, Hans-Georg. Verdade e método II. Tradução de Ênio Paulo Giachini. Petrópolis: Vozes, 2002.

GRAU, Eros Roberto. Por que tenho medo dos juízes. 7. ed. São Paulo: Malheiros, 2016.

GUASTINI, Riccardo. Das fontes às normas. Tradução Edson Bini. São Paulo: Quartier Latin, 2005.

GUASTINI, Riccardo. Las fuentes del derecho: fundamentos teóricos. Traducción César E. Moreno More e Luis Cárdenas Rodríguez. Lima: Raguel, 2016,

GUIMARÃES, Hélio de Seixas; LESSA, Ana Cecília. Figuras de linguagem: teoria e prática. 14. ed. São Paulo: Atual, 2003.

HART, H. L. A. O conceito de direito. Tradução de A. Ribeiro Mendes. 3. ed. Lisboa: Calouste Gulbenkian, 2001.

HESSE, Konrad. Temas fundamentais do direito constitucional. Textos selecionados e traduzidos por Carlos dos Santos Almeida et al. São Paulo: Saraiva, 2009.

KANT, Immanuel. Crítica da razão pura. Tradução de Valerio Rohden e Udo Baldur Moosburger. São Paulo: Nova Cultural, 1999.

KELSEN, Hans. Teoria pura do Direito. Tradução de João Baptista Machado. 6. ed. Coimbra: Arménio Amado, 1984.

KELSEN, Hans. O problema da justiça. Tradução João Baptista Machado. 4. ed. São Paulo: Martins Fontes, 2003.

KELSEN, Hans. Causalidade e imputação. In: KELSEN, Hans. O que é a Justiça? Tradução Luís Carlos Borges. 3. ed. São Paulo: Martins Fontes, 2001. p. 323-348.

LARENZ, Karl. Metodologia da ciência do direito. Tradução de José Lamego. 3. ed. Lisboa: Fundação Calouste Gulbenkian, 1997.

LUHMANN, Nicklas. Sociologia do Direito II. Tradução de Gustavo Bayer. Rio de Janeiro: Tempo Brasileiro, 1985.

MARTINS, Ricardo Marcondes. Teoria dos princípios formais. In: FERNANDES, Felipe Gonçalves (org.). Temas atuais de direito administrativo neoconstitucional. São Paulo: Intelecto, 2016. p. 01-37. 
MARTINS, Ricardo Marcondes. Efeitos dos vícios do ato administrativo. São Paulo: Malheiros, 2008.

MARTINS, Ricardo Marcondes. Proporcionalidade e boa administração. Revista Internacional de Direito Público (RIDP), Belo Horizonte, ano 2, n. 2. p. 09-33, jan./jun. 2017.

MARTINS, Ricardo Marcondes. Abuso de direito e a constitucionalização do direito privado. São Paulo: Malheiros, 2010.

MARTINS, Ricardo Marcondes. Teoria jurídica da liberdade. São Paulo: Contracorrente, 2015.

MARTINS, Ricardo Marcondes. Estudos de direito administrativo neoconstitucional. São Paulo: Malheiros, 2015.

MARTINS, Ricardo Marcondes. Regulação administrativa à luz da Constituição Federal. São Paulo: Malheiros, 2010.

MOUSSALLEM, Tárek Moysés. Fontes do direito tributário. São Paulo: Max Limonad, 2011.

NEVES, Marcelo. Entre Hidra e Hércules: princípios e regras constitucionais. São Paulo: Martins Fontes, 2013.

PERLINGIERI, Pietro. Perfis do direito civil: introdução ao direito civil constitucional. Tradução Maria Cristina De Cicco. 2. ed. Rio de Janeiro: Renovar, 2002.

QUEIRÓ, Afonso Rodrigues. O poder discricionário da administração. 2. ed. Coimbra: Coimbra, 1948.

QUEIRÓ, Afonso Rodrigues. A teoria do "desvio de poder" em direito administrativo. Revista de Direito Administrativo, Rio de Janeiro, v. 6. p. 41-78, 1946.

REALE, Miguel. Filosofia do direito. 19. ed., 3. tir. São Paulo: Saraiva, 2002.

SANTIAGO NINO, Carlos. Introdução à análise do direito. Tradução de Elza Maria Gasparotto. São Paulo: WMF Martins Fontes, 2015.

SCHLEIERMACHER, Friedrich D. E. Hermenêutica: arte e técnica da interpretação. Tradução de Celso Reni Braida. 4. ed. Bragança Paulista: Editora Universitária São Francisco, 2003.

$\mathrm{SCHWABE}$, Jürgen. Cinquenta anos de jurisprudência do tribunal constitucional federal alemão. Tradução Beatriz Hennig et al. Montevideo: Konrad-Adenauer-Stiftung, 2005.

SERRANO, Pedro Estevam Alves Pinto. 0 desvio de poder na função legislativa. São Paulo: FTD, 1997.

SILVA, Virgílio Afonso da. A constitucionalização do direito. São Paulo: Malheiros, 2005.

SUNDFELD, Carlos Ari. Princípio é preguiça? In: SUNDFELD, Carlos Ari. Direito administrativo para céticos. 2. ed. São Paulo: Malheiros, 2014, 205-229. 
TÁCITO, Caio. O abuso de poder administrativo no Brasil. In: TÁCITO, Caio. Temas de direito público: estudos e pareceres - v. 1. Rio de Janeiro: Renovar, 1997. p. 39-70.

TELLES JUNIOR, Goffredo. O direito quântico. 6. ed. São Paulo: Max Limonad, 1985.

VILANOVA, Lourival. As estruturas lógicas e o sistema do direito positivo. São Paulo: Max Limonad, 1997. 